\title{
Monetising the social value of inclusive entrepreneurship: the case of the Abono Café social economy enterprise
}

\section{Virginia Barba-Sánchez, Yolanda Salinero y Pedro Jiménez Estévez}

\begin{abstract}
The fact that so many people with disabilities are unemployed is a cause for concern among those responsible for employment and creating social policies, and also for families and stakeholders themselves. Self-employment, which is understood as the creation of businesses, could be a means to mitigate this problem. The market evaluation of this type of company should consider not only its economic, but also its social results in terms of both cost savings for various public administrations and the generation of social value. This includes taking advantage of the talent of an important part of the population or increasing the wellbeing of people with disabilities, thus making decent employment possible as regards all that is sought by Sustainable Development Objective (SDA) 8 of the United Nations (UN) Agenda 2030. The objective of this work is, therefore, to monetise the social value of this type of undertaking through the use of a case study: that of the Abono Café company. The results show that the non-market value of this company greatly exceeds its market value, thus confirming its potential to generate social value for its stakeholders. The multiplying effect of the funds that Public Administrations allocate to the promotion of this type of initiative among people with disabilities makes them a useful tool and represents a change in the design of public policies, both on a social and employment level.

KEYWORDS: Social value, inclusive entrepreneurship, social economy, SPOLY, stakeholders.

ECONLIT DESCRIPTORS: A13, L31, M14.

How to cite this article: BARBA-SÁNCHEZ, V., SALINERO, Y. \& JIMÉNEZ-ESTÉVEZ, P. (2021): "Monetising the social value of inclusive entrepreneurship: the case of the Abono Café social economy enterprise ", CIRIEC-España, Revista de Economía Pública, Social y Cooperativa, 101, 115-141. D0I: 10.7203/CIRIEC-E.101.18158.

Correspondence: Virginia Barba-Sánchez, University of Castilla-La Mancha, Faculty of Computer Science Engineering, virginia.barba@uclm.es, ORCID: 0000-0003-0149-0569; Yolanda Salinero, University of Castilla-La Mancha, Faculty of Social and Juridical Sciences, Yolanda.Salinero@uclm.es, ORCID: 0000-0002-14048406; Pedro Jiménez Estévez, University of Castilla-La Mancha, Faculty of Social and Juridical Sciences, Pedro. jestevez@uclm.es, ORCID: 0000-0001-7295-4127.
\end{abstract}




\section{Resumen amplio}

\section{Monetizar el valor social del emprendimiento inclusivo: el caso de la empresa de economía social Abono Café}

\section{Objetivos}

En un entorno caracterizado por altas tasas de desempleo entre las personas con discapacidad, este trabajo tiene como objetivo demostrar que el emprendimiento es una alternativa útil al empleo por cuenta ajena (Barba-Sánchez et al., 2019), que contribuye a la inclusión social de las personas con discapacidad y que genera un valor social cuantificable en términos de valor social. Además, autores como Pagán (2009) y Halabisky (2014) consideran que esta alternativa es apropiada para las personas con discapacidad, ya que puede darles una mayor flexibilidad laboral en cuanto a la carga de trabajo y las horas del mismo, permitiendo así un mejor equilibrio entre su discapacidad y su vida laboral. Akinyemi (2016) señala que el autoempleo da a las personas con discapacidad la oportunidad de ser miembros productivos de la sociedad, lo que, según Seelman (2008), aumenta su autoestima y confianza en sí mismos.

\section{Metodología}

Dado que el emprendimiento por parte de personas con discapacidad es un fenómeno poco estudiado, a través de la pregunta de investigación tratamos de averiguar cómo este tipo de emprendimientos generan valor social. El método del caso es particularmente válido al buscar la generalización y la inferencia hacía la teoría (Yin, 2014). Además, para conseguir el objetivo propuesto de monetizar el valor social vamos a usar el Modelo Poliédrico de San José y Retolaza (2016).

Basado en la Teoría de los Stakeholders de Freeman (1984), el Modelo Poliédrico de San-José y Retolaza (2016), también conocido como SPOLY, se sustenta en la idea de que una organización genera valor a los distintos grupos de interés con los que interactúa. Sin embargo, la perspectiva contable tradicional sólo recoge el valor generado para el factor capital, a través del beneficio contable.

Para aplicar la metodología de este Modelo Poliédrico de San-José y Retolaza (2016). se han identificado a los grupos de interés de la empresa de economía social "Abono Café" y, por medio de una serie de entrevistas a los principales stakeholders o grupos de interés implicados, se han identificado también las variables de valor orientadas a indicadores, cuya cuantificación permitirá aproximarnos al valor social generado por Abono Café. 


\section{Resultados}

Entre los resultados, destaca el cálculo del Valor Social Integrado (VSI) generado por Abono Café, que asciende a 566.548,99 €. Para ello debíamos determinar el Valor Social de Mercado (VSM), el Valor Social Específico (VSE) y el Valor Emocional (VE); sin embargo, este último todavía está en fase experimental (Román et al., 2020), por lo que hemos centrado este trabajo en los dos primeros. Así pues, el Valor Social Integrado (VSI) de Abono Café se ha calculado sumando el Valor Social de Mercado (VSM), compuesto por el Valor Socio-Económico y el Valor Movilizado, y el Valor Social Específico (VSE). En concreto, el VSE de Abono Café (347.814,00 $€)$ supera su VSM $(218.734,99 €)$, lo que es indicativo del potencial social de este tipo de iniciativas y está en consonancia con su principal objetivo, que es la inserción socio-laboral de los socios de la misma, que son personas con discapacidad. Además, el índice de valor social, que indica cuánto valor social genera la empresa a partir de la financiación pública obtenida (San-José, 2019) es 5,37 €, lo que significa que el VSI (566.548,99 €) representa cinco veces la financiación pública recibida (105.450 €), es decir, por cada euro invertido por el gobierno regional en Abono Café genera, al menos, 5,37 €.

\section{Conclusiones y aplicaciones prácticas}

Como principales conclusiones podemos destacar que es posible la cuantificación del valor social de Abono Café, una cooperativa fundada y gestionada por jóvenes con discapacidad, ubicada en Toledo; y que visibilizar iniciativas como ésta, demostrando su viabilidad técnica, económica y social, por sí misma ya genera valor al ser un referente para otras personas en esta misma situación.

Así, las principales implicaciones prácticas tienen que ver con que la generación de valor social por parte de Abono Café demuestra que es una realidad posible, alentadora y ejemplarizante para fomentar el autoempleo para personas con discapacidad y que otras personas en similares circunstancias pueden también tener éxito. Además, también pone en valor la flexibilidad laboral que el autoempleo ofrece a las personas con discapacidad, dado los problemas que este colectivo tiene para compatibilizar su discapacidad con cualquier actividad laboral. Así, se evidencia que el marco del emprendimiento facilita la adaptación al puesto de trabajo, sus funciones y tareas, a un determinado perfil individual.

\section{Limitaciones}

Somos conscientes de las posibles limitaciones, principalmente derivadas de que se trata de una aproximación por defecto, en función del principio de prudencia. Además, en el proceso de cálculo de estos valores hemos detectado oportunidades de mejora en la identificación y definición de indicadores y proxies para futuras investigaciones:

a. En primer lugar, en la tercera variable de valor relativa a la "integración social" se ha medido el número de nuevos contactos que la creación de la empresa ha supuesto para los socios, pero no su calidad, en términos de confianza desarrollada y frecuencia de las interacciones, como sugiere Keyes (1998). 
b. En la sexta variable de valor relacionada con la "confianza y autoestima", se ha consultado a los expertos por una terapia psicológica estándar para fomentar ambos rasgos de personalidad, siendo conscientes de la dificultad de estandarizar un colectivo tan amplio. En este sentido, una mejora para futuros cálculos tendría que recoger diversidad de terapias en función del tipo y grado de discapacidad de los socios de Abono Café.

c. En relación con la séptima variable de valor referida al "bienestar", se ha observado una reducción de visitas médicas de los socios tras la creación de la empresa, pero no hemos sido capaces de contabilizarla. En el caso de este tipo de entidades, sugerimos que el cálculo no se haga a posteriori, es decir, con los datos del ejercicio económico cerrado, sino que haya un trabajo previo de identificación y medición de indicadores de las variables de valor para el cálculo del valor de no mercado durante el ejercicio que se quiera monetizar, dejando el cálculo del valor de mercado para el siguiente ejercicio económico, tras el cierre contable.

\section{Futuras líneas de investigación}

Al hablar de posibles líneas futuras de investigación debemos señalar que, en general, el reto para la generalización del uso de esta metodología es la estandarización, aunque sea por sectores de actividad u otras características diferenciadoras. Dado que el proceso de aplicación todavía resulta largo y complejo, necesitando de personal cualificado para su correcta implementación, sobre todo para la identificación de las variables de valor específicas, sus indicadores y sus proxies, que es un proceso todavía muy artesanal. Sin duda, este hecho se deriva de la escasez de investigación aplicada existente hasta la fecha, por lo que este artículo contribuye a la futura estandarización de esta metodología, posibilitando su futura digitalización, al nutrir esa base de datos de variables de valor, indicadores y proxies. En este sentido, se necesitan futuras investigaciones que vayan consolidando la metodología SPOLY, que propone un cambio de visión, pasando del concepto de gasto al de inversión, y que demuestren la viabilidad de este cambio de paradigma.

\section{Contribuciones}

La novedad y originalidad que este trabajo aporta es que, si bien esta metodología se ha aplicado antes a otras empresas de economía social (Retolaza et al., 2014; Román et al., 2020), dos son las principales aportaciones de este trabajo de investigación: identifica las variables de valor presentes en una empresa fundada por personas con discapacidad, en su mayoría intelectual; $y$, dado que la empresa analizada se dedicada a la elaboración de humus, muchas de las variables de valor identificadas son totalmente novedosas e inéditas en el ámbito de la aplicación del modelo SPOLY y servirán de base para la futura aplicación a otras empresas dedicadas a este tipo de actividad.

Palabras clave: Valor social, emprendimiento inclusivo, economía social, SPOLY, stakeholders. 


\section{Introduction}

In an environment characterised by high unemployment rates among people with disabilities, the social inclusion of this group is undermined by their economic dependence on both their families and public institutions (ODISMET, 2018). According to data obtained from the Spanish National Institution of Statistics (INE (2018)), in 2017, the unemployment rate of people with disabilities in Spain exceeded that of the non-disabled population by more than nine points (26.2\% compared to 17.1), a gap that has remained during the evolution of these data since records began. Although the principal objective of Law 13/1982 (Law on the Social Integration of the Disabled) has been to reduce this gap at a national level in order to achieve the full social integration of this group, we have observed that this has not, in reality, been the case; the relevance of this problem is highlighted by the fact that, at a national level, almost two million people of working age (from 16 to 64 years old) have some kind of disability that is either permanent or temporary, which represents $6.2 \%$ of the total working population (INE, 2018). At the European Union (EU) level, this percentage is about 16 per cent, and is likely to increase as the population ages (Halabisky, 2014).

According to Manzanera-Román and Brändle (2019), employment is one of the most effective elements as regards integrating people into society. Authors such as Bengioshu and Balta (2011) suggest that the use of people with disabilities would improve the quality of service and efficiency, thus reducing the costs of the employing company. In practice, however, discrimination by employers plays an important role in the low employment rates of people with disabilities (Beisland, Mersland and Zamore, 2016), while those who find employment tend to be do so in badly-paid jobs that require few skills (Meager and Higgins, 2011).

Entrepreneurship is, in this context, a useful alternative (Barba-Sánchez et al., 2019) that contributes to the social inclusion of people with disabilities. Furthermore, authors such as Pagán (2009) and Halabisky (2014) consider that this alternative is appropriate for people with disabilities, as it can give them greater flexibility in terms of their workload and working hours, thus allowing a better balance between their disability and their working life. Akinyemi (2016) states that self-employment gives people with disabilities the opportunity to be productive members of society, which, according to Seelman (2008), increases their self-esteem and self-confidence. In fact, according to Galle and Lacho (2009), in the United States, people with disabilities are more than twice as likely to be self-employed.

However, inclusive entrepreneurship, and more specifically, inclusive entrepreneurship by people with disabilities, is a topic that is barely addressed in either specialised literature or by the public policies that promote it (Muñoz et al., 2019). The objective of this paper is, therefore, to contribute to the study of entrepreneurship in the case of people with disabilities by investigating the social value that this generates. We have specifically followed the methodology of the San-José and Retolaza Polyhedral Model (2016) in order to identify both the interest groups of the Abono Café social economy company and the indicator-oriented value variables, whose quantification allowed us to approximate the social value generated by Abono Café. 
This latter objective was achieved by means of a series of interviews with the main stakeholders or interest groups involved.

In the following section we shall, therefore, analyse the virtually non-existent theoretical framework regarding entrepreneurship by people with disabilities, after which we shall show the methodology used to monetise the social value of this type of company. The results, which are included in the fourth section, led to a series of conclusions and final recommendations, which are shown in the last section.

\section{Entrepreneurship by people with disabilities and the generation of social value}

Specialised literature (Mackelprang et al., 2016; Maritz and Laferriere, 2016; Uribe-Toril et al., 2019) increasingly considers that people with disabilities are simply different from others, rather than considering that they have a physical and/or mental condition that limits their options, thus banishing the disability paradigm in favour of diversity. In this respect, Galle and Lacho (2009) have proposed a specific model to deal with this diversity and favour the success of this type of business initiatives, which comprises the following phases, in which the existence of a support team is fundamental to their success.

1. Evaluate the business potential of the specific individual or individuals who will form the entrepreneurial team, analysing their competences and skills for entrepreneurship.

2. Identify and develop a business idea, evaluating its viability.

3. Design and implement a training plan adjusted to the needs and deficiencies of the future entrepreneurial team.

4. Obtain technical assistance related to entrepreneurship.

5. Develop the business plan.

6. Explore and request resources from other sources, such as social assistance related to disability or job generation.

7. The review of the self-employment plan by the agency (or support team) promoting the entrepreneurship programme.

8. Monitoring (by the support team).

Although all phases of the proposed model are relevant, training is vital to the success of the project. In this respect, Raposo et al. (2008), in a study involving university students, demonstrated the important effect of education on the propensity to create a business. The results point to the importance of entrepreneurship education and the promotion of entrepreneurial intent. In other words, entrepreneurial intent is significantly predicted by entrepreneurship education. Other research has reached similar conclusions (Kennedy et al., 2003; Brice 2004; Li, 2006; Florin et al., 2007). In the field of entrepreneurship by people with disabilities, the 
importance of training is highlighted as regards not only promoting entrepreneurship, but also improving the chances of survival and profitability of the company created (García-Palma and Sánchez-Mora, 2019).

A great number of universities offer certifications and postgraduate degrees in Entrepreneurship, while others offer doctoral programs as a means to prepare a new generation of academics. Yet other universities organise their own training courses and methodologies in order to stimulate entrepreneurial skills and enable the transfer of knowledge to the market. This is the case of the University of Castilla-La Mancha, which has pioneered a course in Inclusive Entrepreneurship together with the group of social entities CECAP. Both training and the promotion of entrepreneurial initiative have been emphasized on this course. There is also a support team which, as proposed by the Galle and Lacho model (2009), helps entrepreneurial candidates to carry out their project, training and drawing up of the business plan, and provides support in its implementation.

We can ask ourselves many questions at this point. The first could be, what is the definition of a person with a disability? To answer this, we can cite the definition provided by Maritz and Laferriere (2016) for the concept of disability. These authors state that disability is a reality for many people all over the world and has been identified by the World Health Organisation as a challenge confronted by all nations for two main reasons: the ageing of the world's population and the increase in chronic disease rates (World Health Organisation, 2011). It is, therefore, difficult to characterise disability succinctly, as impairment can vary in terms of type, duration, stability and severity. According to the World Health Organisation, disability is a generic term that has three components: (1) impairments, (2) activity limitations and (3) participation restrictions. This is a broad useful basis employed in medicine for the purpose cataloguing, and is known as the International Performance Standards Classification and was established by the World Health Organisation (2011). This includes people who are mentally and physically disadvantaged as regards integrating into the society in which they live.

However, what drives people with disabilities to undertake a business venture? To answer this question, Dhar and Farzana (2017) propose that it is the enabling environment that drives entrepreneurship and can inspire people with disabilities to seek out business opportunities. A supportive environment could, therefore, be created in the form of exclusive business associations and support centres for people with disabilities that could provide a platform on which to share business ideas and offer guidance and support as regards raising seed capital from different entities. Manzanera-Román and Brändle (2019) state that employment is one of the most effective elements by which to integrate people into society. Authors such as Bengioshu and Balta (2011) suggest that the use of people with disabilities would improve the quality of service and efficiency, thus reducing the costs of the employing company. In practice, however, discrimination by employers plays an important role in the low employment rates of people with disabilities (Beisland et al., 2016), while those who gain employment tend to do so in badly-paid jobs that require few skills (Meager and Higgins, 2011).

In the available literature on disability and entrepreneurship, two relatively interchangeable terms are used to describe activities that lead to economic independence: self-employment 
and entrepreneurship (Yamamoto et al., 2011). The two are, however, separate. Self-employment focuses on the performance of a person who works for him or herself for personal gain and income rather than wages obtained from employment (Le, 1999). Self-employment is, from a socio-economic perspective, limiting, as the emphasis is on job creation for one person (Parker Harris et al., 2014). Entrepreneurship, meanwhile, emphasizes the creation or innovation of bringing something new to the market (Schumpeter, 2000). The introduction of innovation into the market includes the activity of business creation. This goes beyond self-employment, as it creates an opportunity for a larger business to be established that has the potential to lead to job creation, thus creating a higher socio-economic status for society (Parker Harris et al., 2014).

Inclusive entrepreneurship contributes to social inclusion by giving everyone an equal opportunity to start and run a business. Target groups are those who are disadvantaged and under-represented in entrepreneurship and self-employment, including young people, women, older people, ethnic minorities, immigrants and people with disabilities (OECD, 2019).

What challenges must people with disabilities confront in order to carry out an act of entrepreneurship? Halabisky (2014) states that, in addition to the general challenges confronted by all employers, employers with disabilities are likely to confront specific barriers as regards entering into and sustaining business activities. Some of these barriers are likely to be deep-seated social and structural constraints that impose severe limits on the life chances of certain groups of people with disabilities. These barriers include:

A. A lack of self-confidence and limited career aspirations.

B. The profit trap. Surveys indicate that there is often a fear of losing the security of a regular income from profits when another income is generated (Boylan and Burchardt, 2002; Doyel, 2002; EMDA, 2009).

C. A lack of relevant business knowledge and skills

D. The difficulty involved in accessing initial capital.

E. Consumer discrimination. Self-employment can be deterred by discrimination on the part of customers, thus reducing the demand for the goods and services produced, in addition to the rewards of self-employment (Boylan and Burchardt, 2002; Jones and Latreille, 2011).

F. Rising labour costs. Some employers with disabilities need to hire assistants to help them to perform tasks that many people without disabilities can do on their own (e.g. moving goods, entering data into software), which increases their labour costs and puts them at a competitive disadvantage (Roni, 2009).

G. A lack of adequate business support services. This barrier has several dimensions owing to the individual nature of disabilities (Boylan and Burchardt, 2002; Doyel, 2002; Pavey, 2006).

- Firstly, business advisors are often reluctant to recommend self-employment as a career option for people with disabilities and sometimes actively seek to discourage it.

- Second, and more importantly, training is not always tailored to individual needs and, therefore, has a limited value for certain programme beneficiaries. 
- Thirdly, support services may not be available in particular formats (e.g. Braille), thus making the support service inaccessible to certain segments of the population with disabilities.

- Fourthly, the premises on which support is provided may not be accessible to people with conditions and impairments that affect their mobility.

- Fifthly, support programmes may use language that is offensive to people with disabilities.

- Sixthly, the diversity of impairments and disability means that some employers with disabilities may not perceive themselves as "disabled" and would prefer to receive support within general services, rather than specific services for people with disabilities.

Given that Abellán and Hidalgo (2011) state that disabilities affect not only individuals but also family groups, the local social and economic environment, society in general and the relevant public administrations, it is reasonable to assume that this type of inclusive venture will also generate value for these stakeholders. The question that concerns us is, therefore, how this project creates value, not only from a traditional point of view, but also from the perspective of the founding partners, which is measured by means of the book profit generated. There is another point of view, with a broader vision that is not only focused on the satisfaction of the owner's objective, which comprises the so-called polyhedral or social value. With regard to the latter, Retolaza et al. (2015) point out that there is a diversity of stakeholders in companies, and that the stakeholders who influence and are influenced by the company have different interests (Freeman, 1984; Freeman et al., 2010). The multi-stakeholder perspective, therefore, shows the different values that each stakeholder can give to the organisation. Depending on those interests, they will give more or less value to the organisation (Argandoña, 2011). This evaluation is consequently complex, because it is necessary to know the real interests of the stakeholders, which is what the value depends on. However, existing literature confirms that the social value is much higher than value from the traditional point of view: the classic book profit (Ayuso et al., 2020).

\section{Methodology}

Given that entrepreneurship by people with disabilities is a little studied phenomenon and that the research question seeks to discover how this type of entrepreneurship generates social value, the case method is particularly valid when seeking generalisation and the inference of a theory (Yin, 2014). Furthermore, in order to achieve the proposed objective of monetising social value, we shall employ the Polyhedral Model of San José and Retolaza (2016). 


\subsection{The case study: Abono Café}

Abono Café is an inclusive enterprise project, which constitutes a Cooperative Society for the Social Integration of Associated Work, dedicated to the creation of ecological humus from coffee grounds by using Californian red worms. This is the first experience of entrepreneurship and socio-labour inclusion in the region of Castilla-La Mancha. It is also the first experience of entrepreneurial training and the creation of a cooperative company formed entirely by people with intellectual disabilities in Spain.

Furthermore, it is the first company to emerge from an entrepreneurial idea studied on the UCLM's own course, first taught in the 2016/2017 academic year. This cooperative was created in 2018 and formed exclusively by students who attended the course and who were mentally handicapped. They have committed themselves to entrepreneurship as a natural response to the economic, social and political reality, in which not everyone has the same opportunities when it comes to accessing a job. The students who attended this course decided to stop waiting for someone to give them an opportunity and to be the ones to generate that opportunity by creating their own company.

The Abono Café cooperative project came into being thanks to the care and support of the Social Business Factory, an incubator and business seedbed for the creation, monitoring and advice of socially inclusive businesses. It should be noted that the Social Business Factory is promoted by the CIES Foundation and collaborates with the CECAP Social Entities Group, the University of Castilla-La Mancha, the Specificity Observatory and the communication and marketing company InCommWeTrust.

This cooperative opted for inclusion in a circular economy business model. They recycle organic waste from bars, cafes and restaurants, which they then use to process fertilizer, and the production and distribution techniques are artisanal and localized. The product has been analysed and tested, attaining satisfactory results in terms of its quality and economic viability.

\subsection{The Polyhedral Model (SPOLY)}

The Polyhedral Model of San-José and Retolaza (2016), also known as SPOLY, is based on Freeman's Stakeholder Theory (1984), and its starting point is the idea that an organisation generates value for the different stakeholders it interacts with. However, the traditional accounting perspective includes only the value generated for the capital factor, through accounting profit. The SPOLY model integrates the value generated for each of the organisation's stakeholders, with the principal innovative characteristic that this value does not have to coincide for all of them (Retolaza et al., 2015). Depending on the interest group for which the assessment is made, the value variables detected may or may not coincide, signifying that the calculation will have a common part, called shared value, and a part derived from each of the particular interest groups in the organisation. The first step when applying this model is, therefore, to identify 
the interest groups through the creation of a stakeholder map. Once this map has been used to identify these groups, dialogue is then established with them in order to identify the outputs that the organisation generates for each of them, which are denominated as value variables. Finally, these variables are monetised by directing them towards indicators, such that a fair value or proxy can be obtained for each.

This consequently makes it possible to obtain the so-called non-market social value, to which it is necessary to add the market social value, which is the set of incomes derived from the organisation's economic activity that it distributes to its interest groups, such as the payment of salaries to its workers or the socio-economic return to the Administration, through the payment of taxes. In the case of purchases made from suppliers, it should be pointed out that the income distributed to them has a multiplier effect, as it contributes indirectly to the payment of salaries or taxes of these suppliers. This market value is, therefore, divided into direct and indirect (Retolaza et al., 2016).

From this perspective, the research has been developed in successive iterations with the company, following the philosophy of the SCRUM methodology, which is employed in order to carry out projects in an agile manner (Schwaber and Sutherland, 2017). This process with an initial meeting with the partners in Abono Café in order to explain the project to them and get them involved. Several work sessions were held to collect the data required to carry out the monetisation of social value. We specifically collaborated with the organisation in order to identify its various stakeholders, and agreed to carry out interviews with the top representatives of all the organisations with which Abono Café is involved, in addition to the members themselves and their families. Open interviews were conducted following the perspective of dialogue proposed by San-José y Retolaza (2016), with only one initial question: Does Abono Café bring any value to you or your organisation? The information obtained allowed us to identify the key value variables required to calculate the value that Abono Café generates for each stakeholder group (non-market value).

An analysis of the profit and loss statement for the period analysed was simultaneously carried out in order to obtain the Direct Social-Economic Value derived from its main activity. Furthermore, after obtaining a list of Abono Cafés suppliers as regards both operating and investment, and obtaining the accounts of these suppliers in the database of the Central de Balances Ibéricos (SABI), the value that Abono Café indirectly generates in its environment was calculated. Both values make up the so-called Social Market Value which, together with the non-market value or Specific Value, make up the Integrated Social Value (San-José y Retolaza, 2016). 


\section{Results}

Given that the objective of this work is to calculate the Integrated Social Value (ISV) generated by Abono Café, and following the methodology proposed by San-José y Retolaza (2016), it is necessary to determine the Social Market Value (SMV), the Specific Social Value (SSV) and the Emotional Value (EV). However, the latter is still in an experimental phase (Román et al., 2020), and in this work we shall, therefore, focus on the first two.

\subsection{Social Market Value}

According to Retolaza et al. (2015), the Social Market Value (SMV) is made up of the Direct Socio-Economic Value (DSSV) and the Indirect Socio-Economic Value (ISSV) and includes the social value that Abono Café generates in its main economic activity: humus production. Owing to the growing competition in this sector, the price of humus is falling, and Abono Café is consequently considering turning its production around and diversifying towards the production of mushrooms for gourmet restaurants, as this product generates greater added value and more profit could be obtained than from the sale of humus alone. Moreover, its own humus would also be used for mushroom production. This new activity is not included in the results of this work, as its viability was being studied during the reference period.

\section{a. Direct Social-Economic Value}

The Direct Socio-Economic Value (DSEV) generated by Abono Café amounts to 215,308.89 euros (Table 1) and is distributed among the members of which this cooperative is formed through their salaries (30.58\%), the Public Administrations (P.A.) through contributions to Social Security and taxes $(2.19 \%)$ and the financial suppliers in the form of interest and fees $(0.27 \%)$. The remainder (66.96\%) is retained by Abono Café for subsequent years. It should be noted that these data are affected by a subsidy, amounting to 105,450 euros, which the JCCM granted to this cooperative through the CREA programme, which supports training and employment projects such as this. 
Table 1. Abono Café's Direct Socio-Economic Value

\begin{tabular}{lr} 
Value ecosystems & Monetary value \\
\hline Distributed generated value & $\mathbf{7 2 , 0 6 7 . 7 5} €$ \\
\hline Net wages & $65,833.93 €$ \\
\hline Social Security & $3,679.35 €$ \\
\hline PERSONAL INCOME TAX & $1,036.84 €$ \\
\hline Financial Suppliers & $578.55 €$ \\
\hline Retained generated value & $\mathbf{1 4 4 , 1 8 0 . 2 2} €$ \\
\hline Retained by the Organisation & $144,180.22 €$ \\
\hline \multicolumn{1}{c}{ Direct Socio-Economic Value } & $\mathbf{2 1 5 , 3 0 8 . 8 9} €$ \\
\hline
\end{tabular}

Source: The authors.

\section{b. Indirect Socio-Economic Value}

Furthermore, Abono Café's market activity involves making purchases from suppliers, both for exploitation and investment, which indirectly generates value for its suppliers; value that is, in turn, partially distributed to both the workers and various public authorities. (Retolaza et al., 2015). In this case, $98.13 \%$ are local suppliers from the city of Toledo, which makes the impact of this company more immediate in its environment.

After obtaining Abono Café's list of suppliers, we searched for them in the Iberian Central Balance Sheet Data Office (SABI) database to discover the company's operating income, added value, staff costs and results for the year. This information was then employed to calculate the impact indices in order to establish what part of the value generated by the income obtained from Abono Café is distributed via net salaries, social security, income tax, VAT and results. Table 2 details the value mobilised by suppliers or Indirect Socio-Economic Value (VSE-I) and how it is distributed, differentiating between operating and investment suppliers. In the case of the latter, it should be noted that the monetary value of the year's results is negative owing to the fact that the average for the sector was a loss. Knowing, moreover, that the majority of suppliers are small, helping these companies in difficulty reinforces Abono Café's business culture on the basis of supporting people and not on that of profit.

Finally, the value mobilised by Abono Café was 3,426.10 euros, of which 37.19\% was distributed to their suppliers' workers and $61.93 \%$ constituted a return to the public authorities in the form of social security contributions and taxes. 
Table 2. Value Mobilised by Abono Café

Value ecosystems

Monetary value

Value Mobilised by Operating Suppliers

$2.632,81 €$

Net wages

$956,17 €$

Social Security $789,87 €$

PERSONAL INCOME TAX $332,58 €$

VAT $456,90 €$

Annual profit $97,29 €$

Value mobilised by investment suppliers $793.29 €$

Net wages $317,97 €$

Social Security $274,60 €$

PERSONAL INCOME TAX $130,07 €$

VAT $137,66 €$

Annual profit $-67,01 €$

Source: The authors.

\subsection{Specific Social Value}

The Specific Social Value (SSV) was calculated by identifying the stakeholders in order to interview them and obtain the value variables, i.e., what Abono Café generates as regards the value for them that is complementary to the possible added value in the market relationship. Once the variables had been obtained, the indicators and proxies were identified in order to monetise them and obtain the SSV.

\section{a. Identification of stakeholders}

The stakeholders that receive the social value of the non-market of coffee fertilizer are the following:

- Management team. This is made up of a President, Secretary and the Treasurer.

- Partners. This cooperative is formed of 14 members ( 9 women and 5 men). 
- Support staff. Throughout the process, the cooperative members have received the support of a member of the social entity CECAP, who assigns to each cooperative member the task that may interest him/her most and in which s/he can best develop his/her capacities. The members have also been supported by the Social Business Factory (SBF), which is an incubator and business seedbed for the creation and monitoring of and provision of advice for socially inclusive companies, promoted by the CIES Foundation and collaborating with the CECAP Group of Entities, the UCLM, the Observatory of Specificity and the communication and marketing company InCommWeTrust. Finally, some employees of La Caixa Bank have collaborated voluntarily in various advisory tasks.

- Families. During the entire training process, the creation of the company and the carrying out of the business activity, a very important and basic pillar is the support and interest of the students' families. They are not only mere spectators of the project, but also get involved and help the pupils with certain activities (something that makes the family ties even stronger).

- Suppliers. Of the suppliers, we should highlight those that provide the raw material, which comprise the network of collaborating cafeterias, that which provides the facilities, El Cigarral del Ángel Custodio de Toledo, or that which provided the training required to carry out this project, the University of Castilla-La Mancha (UCLM) and the School of Industrial Organisation (EOI). In this respect, it should be pointed out that El Cigarral provided a space and a tent in which to enable the students to start testing what the production of humus would be like (in terms of characteristics, quantity, etc.); while the training given at the UCLM on its own course "Inclusive Entrepreneurship", a pioneer in Spain, had the objective of students acquiring knowledge of entrepreneurship in order to be able to develop their professional life through self-employment.

- Customers. The El Greco Museum in Toledo was their first customer and bought all their production. In addition, not only does it continue buying them the humus for its gardens from them, but members of Abono Café now also go to the museum to give gardening courses for children, as an additional activity for the museum. This activity motivates them and gives them self-confidence, since they feel that they can teach things that they know and experience in their daily activities at the company.

- Public administrations. Toledo City Council has supported Abono Café in the consolidation of its project, offering them a space in which they could start. In the words of the Mayor, "it has been a real innovative experience, in which we believe". Inclusive entrepreneurship is, therefore, a reality in the city of Toledo, which is the first municipality in the whole of Castilla-La Mancha to support this type of project. For its part, the JCCM granted them a CREA project (public aid for Training and Employment projects).

- Social environment. Residents in the neighbourhood of Abono Café's facilities and local associations with common objectives to those of this company.

In summary, Abono Café's principal stakeholders are shown in illustration 1. 


\section{Illustration 1. Map of the Abono Café company's stakeholders}

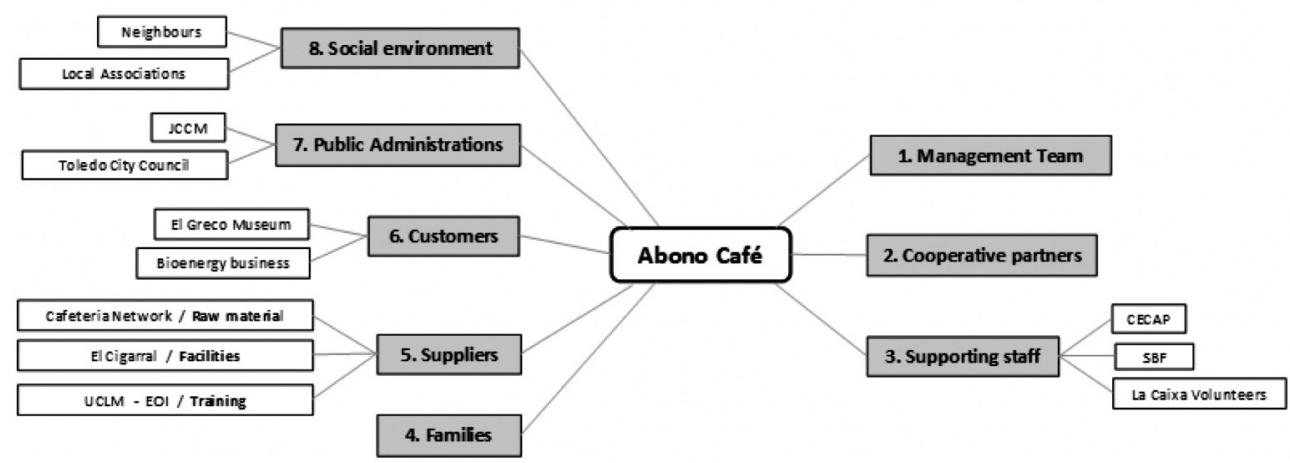

\section{b. Analysis of stakeholders' interests: value variables}

Once Abono Café's main groups of stakeholders had been identified, 25 interviews were carried out with representatives of these groups, which is, according to the experience of San-José y Retolaza (2016: 91), more than sufficient for a company of this size (14 partner-workers): "From our experience, it could be deduced that, for medium-sized entities (50-250 workers), between fifteen and twenty-five interviews seems a correct number". The purpose of the interviews is to identify the value variables, to a lesser extent than quantifying the value they generate, thus enabling the various stakeholders to identify similar value variables. It should be noted that these interviews were carried out with all the partners of this cooperative, including the management team, the Mayor of Toledo and several representatives of CECAP, without whom this work would not have been possible, given the involvement they have had in both the creation and the day-to-day management of this company.

After the information was collected, the value variables provided by each interest group were ordered and reformulated so as to homogenise their names and orient them towards indicators, as suggested by San-José and Retolaza (2016). We have, therefore, obtained the following value variables:

- The "creation of positions at the company" is related to the capacity to generate employment. In this respect, one of the principal future objectives of this initiative is, in addition to ensuring the innate survival of the organisation, to continue growing and to increase the number of members in the cooperative

- $\quad$ They have difficulties in applying for certain positions with better working conditions and which require previous experience. This type of initiative makes it easier for them to access such positions.

- "Labour integration" refers to the improvement to employability that originates from creating and managing one's own business. The experience and knowledge acquired serve 
the partners as regards not only continuing with and improving the current project, but also increasing their curriculum and gaining more employment options. Given that the labour market values previous experience very positively, young people in general, and young people with disabilities in particular, have, in many cases, difficulties when applying for certain positions with better working conditions and which require previous experience. This type of initiative makes it easier for them to access such positions

- "Social integration" refers to the increase in professional networks before and after the creation of the company. Having a greater network of contacts contributes both to labour insertion and mobility (Vacchiano et al., 2018) and to alleviating and preventing social isolation (Bolíbar, 2011).

- The value generated by the variable "economic independence" is derived from the possibility of emancipation that comes with earning money from one's work. According to Pérez Camarero et al. (2006), this is one of the requirements to overcome the youth phase and start a full adult life.

- "Sustainability" is related to the fact that the main raw material is coffee grounds, which the company collects directly from the local cafeterias. A waste product is reused to produce another product, humus, in a practical example of a circular economy.

- Confidence and self-esteem have to do with improving these facets of the cooperative members' personality. The self-confidence that comes from having created a company and being a productive part of society increases the value that these people with disabilities perceive in themselves and of their own abilities, thus blurring the limits that may, on many occasions, have been imposed owing to social prejudices.

- This point is related to the previous one and to the perception of both labour and social intergration. "Welfare" is related to an improvement to the members' mood that transcends in their daily life and in their relationships with others.

- Social responsibility" refers to the value that this company generates by making it possible to fulfil the social objectives of public and private entities and institutions, such as the JCCM or the El Greco Museum.

- The "social references" have to do with the fact that the members of Abono Café can serve as a model for all those people with disabilities who find themselves without work or unsatisfied with their current work. According to the Social Learning Theory (Bandura, 1977), role models have a considerable influence on people's behaviour, signifying that the example of entrepreneurial people can be genuinely effective as regards encouraging entrepreneurship (Liñan and Fayolle, 2015), but only if the group they are addressing feels identified with them (Nowinski and Haddoud, 2019), as is the case here.

- Finally, "personal independence" is related to the ability to make one's own decisions and not depend on others in one's daily life, from a physical and not only an economic point of view. 
a. Monetary valuation of value variables: VSE

- $\quad$ Table 3 shows the monetary valuation of the value variables, specifying indicators, outputs, reference value and proxies, which amounts to $347,814 €$.

- The indicator used to monetise the "job creation" variable is the number of workers inserted and the subsidy available for hiring people with disabilities granted by the Junta de Comunidades de Castilla-La Mancha (JCCM, 2020) as a proxy, given the savings that such initiatives represent for the JCCM.

- With regard to "labour integration", two indicators are used: the hours of training received in business creation and management by all the members of the cooperative and those received in management training by two of the members of the management team. The proxies are related to the shadow prices of this type of training.

- In order to measure "social integration", the partners were asked about their networks before and after the creation of the company, obtaining the joint difference in the number of contacts. Since we understand that professional associations are an alternative way in which to obtain professional contacts, we have chosen to use the registration fee paid to the Association of Self-Employed Workers (ATA) as a proxy. It should be noted that the fee of 20 euros that must be paid is a complement to that of the specific professional association depending on the sector of activity, to which one must also be registered in order to become a member of the ATA.

- In the case of "economic independence", both the indicator and the proxy coincide with the average annual salary actually received by the partners.

- The indicator used to measure "sustainability" has been that of the kilos of waste collected and reused for the manufacture of humus. The waste collection fee established for other green point materials has been used as a proxy (Ecoembes, 2020).

- In the interviews with the cooperative's members, they all declared an increase in "confidence and self-esteem" thanks to their participation in this initiative, and we, therefore, believe that the indicator should be precisely this improvement. However, the difficulty involved in monetising it means that the proxy chosen has to do with an alternative means of achieving a similar result which, according to the psychologists consulted, would be one session once a week for about a year.

- With regard to "well-being", the indicator used was the reduction in medical visits, although it was not possible in the interviews to determine by what proportion they have decreased since the creation of the company and, given the confidentiality of this medical data, it was possible to obtain it by other means. The proxy used was consequently the monthly fee for a standard private medical insurance, which is understood to be a saving to the public health system, by reducing the frequency of the members' medical visits.

- As an indicator of "social responsibility" we have used the number of stakeholders who identify this value variable as being relevant, in line with what is proposed by Román Cervantes et al. Given that these stakeholders' collaboration with Abono Café has been monitored by various media, the proxy used has been the price of an advertising campaign, as suggested by Marketinguerrilla (2020). We have again chosen to use the minimum value of the range. 


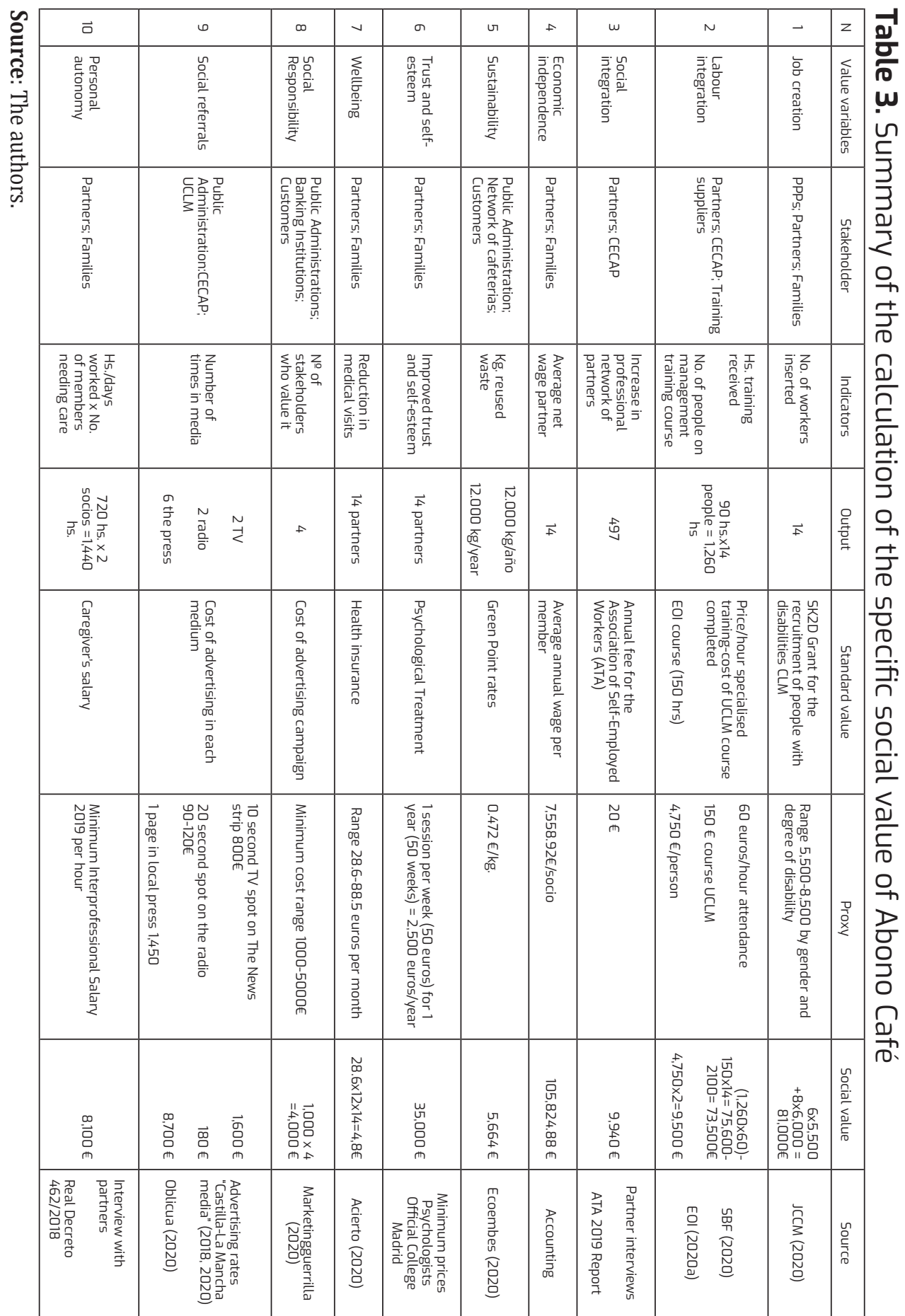


- We have monetised the value of "social references" by using the number of times that Abono Café has appeared in the media as an indicator, and the rates of the different media (television, radio and press) as a proxy.

- Two of the partners in Abono Cafés had a permanent caregiver, although they have been able to do without one during working hours. In this respect, the indicator used to measure "personal independence" is the average number of hours worked in Abono Café and the proxy is the minimum inter-professional hourly wage that the caregiver should at least be paid.

\subsection{Integrated Social Value}

As shown in Table 4, the Integrated Social Value (ISV) of Abono Café is, according to Retolaza et al. (2016), calculated by adding the Social Market Value (SMV), composed of the Socio-Economic Value and the Mobilized Value, and the Specific Social Value (SSV). The SMP of this company, therefore, amounts to 566,548.99 euros. We should point out that, in this company, the SVE is higher than the SVM, which is in line with its main objective, i.e., the social and labour insertion of the company's partners, who are people with disabilities. Furthermore, the social value index, which indicates how much social value the company generates from the public funding obtained (San-José, 2019), is 5.37 euros.

Table 4. Integrated Social Value of Abono Café

\begin{tabular}{lr} 
Value ecosystems & Monetary value \\
\hline Social Market Value & $218,734.99 €$ \\
\hline Socio-Economic Value & $215,308.89 €$ \\
\hline Mobilised Value & $3,426.10 €$ \\
\hline Specific Social Value & $347,814.00 €$ \\
\hline Integrated Social Value & $\mathbf{5 6 6 , 5 4 8 . 9 9 €}$ \\
\hline
\end{tabular}

Source: The authors. 


\section{Conclusions}

The aim of this research is to quantify the Integrated Social Value (ISV) of Abono Café, a cooperative located in Toledo that was founded and managed by young people with disabilities. This work also allows us to make initiatives like this visible and give them value. On many occasions, there is a belief that this type of project does not generate value, and is only a social cost that is more inherent to the social system derived from our values and ethics as a Society. However, for the CECAP Group of Social Entities, the experience of Abono Café, as a project led by young people in a situation of social vulnerability owing to their disability, can be seen in a different light: the first is that it is a possible reality, encouraging and exemplary for other people in similar circumstances; and the second is the labour flexibility that self-employment offers, given the problems that this group has in making their disability compatible with any labour activity. It is, therefore, evident that the framework of the enterprise facilitates the adaptation of the job, its functions and tasks, to a certain individual profile, as also concluded by Kirkwood and Tootell (2008).

Although this methodology has been applied before to other social economic enterprises (Retolaza et al., 2014; Román et al., 2020), this research work is innovative in two principal respects: it identifies the value variables present in an enterprise, firstly, founded by people with disabilities and, secondly, dedicated to the manufacture of humus. Many of the value variables identified are, therefore, totally new and unprecedented in the field of the application of the SPOLY model and will serve as a basis for future application to other companies founded and managed by people with disabilities.

Although we are aware that this is a default approach, in accordance with the principle of prudence, the Specific Social Value of Abono Café (347,814.00 euros) exceeds its SVA (218,734.99 euros), which is indicative of the social potential of this type of initiative. Furthermore, we must highlight that the Integrated Social Value (566,548.99 euros) represents five times the public funding received (105,450 euros), i.e. for every euro invested by the JCCM, Abono Café generates at least 5.37 euros.

However, during the process of calculating these values, we detected opportunities for improvement as regards identifying and defining indicators and proxies for future research. Firstly, in the third value variable relating to "social integration", we measured the number of new contacts that the creation of the company has meant for the partners, but not their quality, in terms of trust developed and frequency of interactions, as suggested by Keyes (1998). Secondly, in the sixth value variable related to "confidence and self-esteem", experts were consulted for standard psychological therapy to promote both personality traits, since we are aware of the difficulty of standardising such a wide group. In this respect, an improvement to future calculations would have to include a diversity of therapies depending on the type and degree of disability of the members of Abono Café. Finally, in relation to the seventh variable of value referring to "well-being", a reduction in the number of medical visits by the partners was observed after the creation of the company, but we were unable to quantify it. In the case of this type of entity, we suggest that the calculation should not be made a posteriori, that is, 
with the data from the closed financial year, but that prior work should be carried out in order to identify and measure indicators of the value variables for the calculation of the non-market value during the financial year to be monetised, leaving the calculation of the market value for the following financial year, after the accounting closure.

In addition, the challenge for the generalisation of the use of this methodology is standardisation, even if it is by activity sectors or other differentiating characteristics, given that the application process is still long and complex, requiring qualified personnel for its correct implementation, particularly in the case of identifying the specific value variables, their indicators and their proxies, which is still a very traditional process. This is, without doubt, derived from the scarcity of applied research existing to date, signifying that this article contributes to the future standardisation of this methodology, making its future digitalisation possible by feeding this database with value variables, indicators and proxies. In this respect, future research is required in order to consolidate the SPOLY methodology, which proposes a change of vision, moving from the concept of expenditure to that of investment, and which demonstrates the viability of this change of paradigm.

\section{References}

ABELLÁN GARCÍA, A. \& HIDALGO CHECA, R.M. (2011): Definiciones de discapacidad en España. Retrieved from http://envejecimiento.csic.es/documentos/documentos/pm-definiciones-01.pdf.

ACIERTO (2020): Comparador de seguros. Disponible en https://www.acierto.com/seguros-salud/comparador/.

AKINYEMI, E.O. (2016): "Enterpreneurial Empowerment of People with Special Needs in Ondo and Osun States, Nigeria", Journal of Arts and Humanities, 5(11), 26-38, https://doi. org/10.18533/journal.v5i11.1013.

ARGANDOÑA, A. (2011): "Stakeholder theory and value creation", Working Paper IESE No. 9, IESE, Business School”, Barcelona, Spain, https://dx.doi.org/10.2139/ssrn.1947317.

AYUSO, S., SÁNCHEZ, P., RETOLAZA, J.L. \& FIGUERAS-MAZ, M. (2020): "Social value analysis: the case of Pompeu Fabra University", Sustainability Accounting, Management and Policy Journal, https://doi.org/10.1108/SAMPJ-11-2018-0307.

BANDURA, A. (1977): Social learning theory, Englewood Cliffs, NJ: Prentice Hall. 
BARBA-SÁNCHEZ, V., ORTÍZ-GARCÍA, P. \& OLAZ-CAPITÁN, A. (2019): "Entrepreneurship and disability: Methodological aspects and measurement instrument", Journal of Entrepreneurship Education, 22(S2), Retrieved from: https://www.abacademies.org/articles/entrepreneurship-and-disability58-methodological-aspects-and-measurement-instrumentsup1sup-8477. html.

BEISLAND, L.A., MERSLAND, R. \& ZAMORE, S. (2016): “Motivations for Business Start-up: Are There any Differences Between Disabled and Non-disabled Microfinance Clients?", Journal of International Development, 28(1), 147-149, https://doi.org/10.1002/jid.3196.

BENGISN, M. \& BALTA, S. (2011): "Employment of the workforce with disabilities in the hospitality industry", Journal of Sustainable Tourism, 19(1) 35-57, https://doi.org/10.1080/0966 9582.2010.499172.

BOLÍBAR, M. (2011): “Las asociaciones en las redes personales. ¿Mecanismo de integración de la población inmigrante?", Redes. Revista hispana para el análisis de redes sociales, 20, 161-187. Retrieved from: https://www.raco.cat/index.php/Redes/article/view/249753/334112

BOYLAN, A. \& BURCHARDT, T. (2002): Barriers to self-employment for disabled people. Report prepared for the Small Business Service, London: Department for Business. Innovation and Skills. Retrieved from http:// www.berr.gov.uk/files/file38357.pdf.

BRICE, J. (2004): "The role of personality dimensions on the formation of entrepreneurial intentions". In: Annual Usasbe National Conference (Vol. 18, pp. 1-9).

CASTILLA-LA MANCHA MEDIA (2018): Tarifas spot TV. Documento interno.

CASTILLA-LA MANCHA MEDIA (2020): Tarifas cuñas de radio. Documento interno.

DHAR, S. \& FARZANA, T. (2017): "Entrepreneurship for Persons with Disabilities in Bangladesh: An Analysis of the Schools of Entrepreneurial Thought Approach", Journal of Economics \& Business Research, 23(2), 151-174.

DOYEL, A.W. (2002): "A realistic perspective of risk in self-employment for people with disabilities", Journal of vocational rehabilitation, 17(2), 115-124.

ECOEMBES (2020): Tarifas Punto Verde para otros materiales (2009-2019). Retrieved from https://www.ecoembes.com/es/empresas/ingresos-punto-verde/tarifa-punto-verde-por-material.

EMDA (East Midlands Development Agency) (2009): Scoping Study into the Business Support Needs of Disabled Entrepreneursin the East Midlands. Retrieved from http://webarchive.nationalarchives.gov.uk/20100113061153/http://www.emda.org.uk/uploaddocuments/disabledentrepreneurScopingReport\%202009.pdf. 
EOI (2020a): Cursos de gestión empresarial. Retrieved from https://www.eoi.es/es/cursos.

EOI (2020b): El programa GO 2 WORK. Retrieved from:

https://www.eoi.es/es/espacios-coworking/toledo.

FLORIN, J., KARRI, R. \& ROSSITER, N. (2007): “Fostering entrepreneurial drive in Business Education: An attitudinal approach", Journal of Management Education, 31(1), 17-42, https://doi.org/10.1177\%2F1052562905282023.

FREEMAN, R.E. (1984): Strategic management: A stakeholder approach, Boston, U.S.: Pitman.

FREEMAN, R.E., HARRISON, J.S., WICKS, A.C., PARMAR, B.L. \& DE COLLE, S. (2010): Stakeholder theory: The state of the art, Cambridge, UK: Cambridge University Press.

GALLE Jr, W.P. \& LACHO, K.J. (2009): "A model for self-employment training for people with disabilities", Academy of Health Care Management Journal, 5(1/2), 53.

GARCÍA-PALMA, M.B. \& MOLINA, M.I.S. (2019): "Disability And Entrepreneurship In Spain: Reality And Initial Hypothesis", Journal of Entrepreneurship Education, 22, 1-6. Retrieved from https://search.proquest.com/scholarly-journals/disability-entrepreneurship-spain-reality-initial/docview/2424967863/se-2?accountid=14513.

HALABISKY, D. (2014): Entrepreneurial Activities in Europe-Entrepreneurship for People with Disabilities, Surrey, UK: OECD Publishing.

INE (2018): El Empleo de las Personas con Discapacidad (EPD): Año 2017. Notas de Prensa, Instituto Nacional de Estadística. Retrieved from https://www.ine.es/prensa/epd_2017.pdf.

JCCM (2020): SK2D Subvenciones destinadas a fomentar la contratación de personas con discapacidad en el mercado ordinario de trabajo en Castilla-La Mancha. Retrieved from: https://www.jccm.es/tramitesygestiones/subvenciones-destinadas-fomentar-la-contratacion-de-personas-con-discapacidad-en.

JONES, M.K. \& LATREILLE, P.L. (2011): "Disability and self-employment: Evidence for the UK", Applied Economics, 43(27), 4161-4178, https://doi.org/10.1080/00036846.2010.489816.

KENNEDY, J., DRENNAN J., RENFROW, P. \& WATSON, B. (2003): "Situational factors and entrepreneurial intentions". Proceedings of the 16th Annual Conference of the Small Enterprise Association of Australia and New Zealand: Ballarat.

KEYES, C.L.M. (1998): “Social well-being”, Social psychology quarterly, 121-140, https://doi.org/10.2307/2787065 
KIRKWOOD, J. \& TOOTELL, B. (2008): "Is entrepreneurship the answer to achieving work-family balance?",Journal of Management and Organization, 14(3), 285-302. Retrieved from: https:// search.proquest.com/scholarly-journals/is-entrepreneurship-answer-achieving-work-family/docview/233255468/se-2?accountid=14513.

LE, A.T. (1999): "Empirical studies of self-employment", Journal of Economic surveys, 13(4), 381-416. https://doi.org/10.1111/1467-6419.00088.

LI, W. (2006): Entrepreneurial intention among international students: testing a model of entrepreneurial intention, USASBE Small Business Advancent National Center.

LIÑÁN, F. \& FAYOLLE, A. (2015): "A systematic literature review on entrepreneurial intentions: citation, thematic analyses, and research agenda". Int Entrep Manag J, 11, 907-933, https://doi.org/10.1007/s11365-015-0356-5.

MACKELPRANG, R.W. \& SALSGIVER, R.O. (2016): Disability: A diversity model approach in human service practice. Oxford University Press. Retrieved from https://www.abacademies.org/ articles/the-type-of-disability-as-a-differential-factor-in-entrepreneurship-8417.html.

MARITZ, A. \& LAFERREIERE, R. (2016): "Entrepreneurship and self-employment for people with disabilities", Australian Journal of Career Development, 25(2), 45-54.

EAGER, N. \& HIGGINS, T. (2011): Disability and skills in a changing economy. UK Commission for Employment and Skills, Briefing Paper Series. Retrieved from https://www.employment-studies.co.uk/resource/disability-and-skills-changing-economy.

MUÑOZ, R.M., SALINERO, Y., PEÑA, I., SÁNCHEZ DE PABLO, J.D. (2019): “Entrepreneurship Education and Disability: An Experience at a Spanish University", Administrative Sciences, 9(2), 34. https://doi.org/10.3390/admsci9020034.

NOWINNSKI, W. \& HADDOUD, M.Y. (2019): "The role of inspiring role models in enhancing entrepreneurial intention", Journal of Business Research, 96, 183-193,

https://doi.org/10.1016/j.jbusres.2018.11.005.

BLICUA (2020): Publicidad en La Tribuna de Toledo. Retrieved from https://www.oblicua.es/ publicidad/publicidad-en-la-tribuna-de-toledo-en-toledo.html.

OECD/European Union (2019): The Missing Entrepreneurs 2019: Policies for Inclusive Entrepreneurship, OECD Publishing, Paris, https://doi.org/10.1787/3ed84801-en.

ODISMET (2018): Observatory on disability and labor market in Spain, In: http://www.odismet.es/. 
PAGÁN, R. (2009): "Self-employment among people with disabilities: evidence for Europe", Disability \& Society, 24(2), 217-229. https://doi.org/10.1080/09687590802652504.

PARKER HARRIS, S., CALDWELL, K. \& RENKO, M. (2014): "Entrepreneurship by any other name: Self-sufficiency versus innovation", Journal of social work in disability \& rehabilitation, 13(4), 317-349, https://doi.org/10.1080/1536710X.2014.961115.

PAVEY, B. (2006): "Human capital, social capital, entrepreneurship and disability: An examination of some current educational trends in the UK", Disability \& Society, 21(3), 217-229. https://doi.org/10.1080/09687590600617337.

PÉREZ CAMARERO, S., HIDALGO VEGA Á. \& CALDERÓN, M.J. (2006): La economía de las personas jóvenes.Instituto de la Juventud, Ministerio de trabajo y Asuntos Sociales, Madrid.

RAPOSO, M., MADEIRA, M.J. \& NAVE, E. (2018): “Supporting new firm's through Entrepreneurship education: a case of a successful course". In: European Conference on Innovation and Entrepreneurship, Vol. 19, pp. 627-634. Academic Conferences International Limited. Retrieved from http://hdl.handle.net/10400.6/6880.

RETOLAZA, J.L., RUIZ-ROQUEÑI, M., SAN-JOSÉ, L. \& JON, B. (2014): Cuantificación del valor social: propuesta metodológica y aplicación al caso de Lantegi Batuak, https://doi.org/10.5569/1134-7147.55.02.

RETOLAZA, J.L., SAN-JOSÉ, L. \& RUIZ-ROQUEÑI, M. (2015): "Monetarizing the social value: theory and evidence", CIRIEC-España, revista de economía pública, social y cooperativa, 83, 43-62. Retrieved from https://www.redalyc.org/pdf/174/17440036003.pdf.

RETOLAZA, J.L., SAN-JOSÉ, L. \& RUÍZ-ROQUEÑI, M. (2016): Social accounting for sustainability: Monetizing the social value. Cham: Springer.

ROMÁN CERVANTES, C., GUZMÁN PÉREZ, B., MENDOZA JIMÉNEZ, J. \& PÉREZ MONTEVERDE, M.V. (2020): "La sostenibilidad social de las SATs: una propuesta de indicadores para su evaluación", REVESCO. Revista de Estudios Cooperativos, 133, e67336.

Retrieved from https://dx.doi.org/10.5209/REVE.67336.

RONI, N.N. \& RIBM, M.M.U. (2009): “Disabled entrepreneurship: A viable route of opportunity for the disabled". In: MMUBS Doctoral Symposium. Retrieved from:

http://www.ribm.mmu.ac.uk/symposium2009/Papers\%2009/Roni,\%20Naheed.pdf.

SAN-JOSÉ, L. \& RETOLAZA, J.L. (2016): Contabilidad social orientada a los stakeholders, Comercial Grupo ANAYA, S.A.

SAN-JOSÉ, L., RETOLAZA, J.L. \& BERNAL, R. (2019): “Índice de valor social añadido: una propuesta para analizar la eficiencia hospitalaria", Gaceta Sanitaria.

Retrieved from https://doi.org/10.1016/j.gaceta.2019.08.011. 
SAN-JOSÉ L., RETOLAZA J.L. \& FREEMAN R.E. (2017): “Stakeholder Engagement at Extanobe: A Case Study of the New Story of Business". In: Freeman R., Kujala J., Sachs S. (eds), Stakeholder Engagement: Clinical Research Cases, Issues in Business Ethics, vol 46. Springer, Cham, https://doi.org/10.1007/978-3-319-62785-4_13.

SBF (2020): IV Edición del Curso Universitario de emprendimiento inclusivo y especificidad. Retrieved from: https://socialbiz.es/index.php/2020/02/17/abierta-la-inscripcion-para-el-iv-curso-universitario-de-emprendimiento-inclusivo-promovido-por-el-grupo-de-entidades-sociales-cecap-y-su-fundacion-ciees/.

SCHUMPETER, J.A. (2020): Entrepreneurship as Innovation. University of Illinois at Urbana-Champaign's Academy for Entrepreneurial Leadership Historical Research Reference in Entrepreneurship, Available at SSRN: https://ssrn.com/abstract=1512266.

SUTHERLAND, M.J. \& SCHWABER, M.K. (2018): The Definitive Guide to Scrum: The Rules of the Game', The Scrum Guide, 2017. Retrieved from: https://www.scrumguides.org/docs/ scrumguide/v2017/2017-Scrum-Guide-US.pdf\#zoom=100.

URIBE-TORIL, J., RUIZ-REAL, J. L., CERESIA, F. \& DE PABLO VALENCIANO, J. (2019): Entrepreneurship and psychological disorders in academic publishing. Journal of Entrepreneurship Education, 22, 1-11. Retrieved from: https://www.abacademies.org/articles/entrepreneurship-and-psychological-disorders-in-academic-publishing-8474.html.

VACCHIANO, M., MARTÍ, J., YEPES-CAYUELA, L. \& VERD, J.M. (2018): Las redes personales en la inserción laboral juvenil en tiempos de crisis. Un análisis en Barcelona/Personal Networks in Job Insertion among Young Adults in Times of Crisis: An Analysis in Barcelona. Reis, 121-139. Retrieved from https://www.jstor.org/stable/44841760.

WORLD HEALTH ORGANISATION (2011): World report on disability. Retrieved from: http://www.who.int/disabilities/world_report/2011/report/en/.

YAMAMOTO, S., UNRUH, D. \& BULLIS, M. (2011): "The viability of self-employment for individuals with disabilities in the United States: A synthesis of the empirical-research literature", Journal of Vocational Rehabilitation, 35(2), 117-127, https://doi.org/10.3233/JVR-2011-0559.

YIN, R.K. (2014): Case study research design and methods, 5th ed. Thousand Oaks, CA: Sage. 
